\title{
Antimicrobial Effects of Quercusinfectoria, MatricariachmomillaExtracts, and AlumAgainst Bacteria Isolated from Woman with Sever Vaginitis
}

Received : 7/12/2017

Accepted : 18/1/2018

\section{Asst. Prof. Dr.Nada KhazalKadhim Hindi ${ }^{1}$, Lec. Dr. Lubna Abdul Muttalib Al-shalah ${ }^{2}$, Lec. Dr. ZainabAdil Ghani Chabuck ${ }^{3}$}

${ }^{1}$ Ph.D. microbiology, Basic and Medical science Department, College of Nursing, University of Babylon, Babylon Province, Iraq.E-mail: nadakhazal@yahoo.comMobil:009647813456613.

${ }^{2} \mathrm{Ph} . \mathrm{D}$. microbiology, Environmental research and studies center, University of Babylon.

${ }^{3}$ M.B.Ch.B., M.Sc.and Ph.D. in microbiology and Genetic, Department of Microbiology, College of Medicine, University of Babylon.

\begin{abstract}
Plant extractis considered as natural, safe, accessible and inexpensive materials has been grown for the treatment of bacterial infections. This workwas carried out to decidethe inhibitory activities of Quercusinfectoria, Matricariachmomillaand Alumon bacterial vaginitis and vaginal yeast infections.

In vitro antimicrobial activity of Quercusinfectoria,Matricariachmomillaand chemical material Alumwere studied against Staphylococcus aureus, streptococcus agalactiae, Enterobacter spp., E. coli,. andcandida albicana. The inhibitory effects of extracts were compared with standard antibiotic ciprofloxacin.

The mean of inhibition zonesthatobtained from these extracts were range from (20-35mm).This study illustrates that the aquatic extracts of these materials can beused as a potential source of unusual antimicrobial agents used for bacterialvaginosis and vaginal yeast infection. Also, bacterial infections werethe highest responsive to plant extracts rather than yeast infection, especiallly Strep agalactiae.
\end{abstract}

Keywords: bacterial vaginosis, Quercusinfectoria,Matricariachmomilla, and chemical material allum.

\section{Introduction}

Vaginal ecosystem is an ecologic niche in which microorganism,physical characteristics $(\mathrm{pH}, \quad$ mucus viscosity,etc)and biochemical processes are in balance (1). Bacterial and vaginal yeast infection caused by excessive growth of bacteria and vaginal yeast infection.This is caused by an imbalance of naturally occurring bacteria in the vagina. The normally dominate species of lactobacilli markedly reduced(2). 
Candida are normally present in the vaginain a small numbers, the excessive growth of candida lead to vaginal yeast infection(3). The number of infected cases caused by either the news, re-emerging, or by pathogens resistant to drugsaredevelopinggradually day by day, and the increased section of the hospitalized patients especially those who are immunocompromised has resulted in an increase of invasive and severe infection (4).Drugs derived from plants remain an essentialstore of medicines, especially in the developing nations, in order to fight serious and severinfectious diseases. Nearly 60 to $80 \%$ of the world's population till our daysusingthe traditional remedies and medicines for the treatment of common illnesses $(5,6)$.

Usage of plants and their products have anextendedhistory whichstarted with general medicine and continue through years, to be incorporated into allopathic and traditional medicine and treatment. Fromancient times, many types of plants species that have different pharmacological activities and properties, where they are known to retainseveral secondary metabolites asconveyed totannins, tirpenes, flavonoids, alkaloids, glycosides, saponins andsteroids which are therefore should be employedin order to fight the disease causing different sever pathogens $(7,8,9,10,11)$.

This work aimed to estimate the effects and activity of some plant extracts against bacterial and yeast vagina infection.

\section{MATERIALS AND METHODS}

\section{Collection of Plants}

Extracts of Quercusinfectoria,Matricariachmomilla and chemical material allum) were preparedin aquatic form.About 50 gram of these plants weresoaked in $100 \mathrm{ml}$ of distillated water, andallowed to stand for 72 hours, thenwere sterilized by filtration (using0.45 Millipore filter). These prepared extracts were considered as the $50 \%$ concentration of each extract (12).

Fresh plants were collected from a food store, then, were cleaned, peeled and sun dried; they werepowdered using an electric blender and placed in a clean container.

\section{Microorganism Collection}

Clinical isolateswere obtained from woman withgenital pruritus and burning sensation. The bacterial isolatesrepresented by;Staph. aureus,Strept. agalactiae, E.coli,Enterobacter spp. and Candida albicana.

These isolates were identified and confirmed by the use ofconventional and traditional biochemical tests and Api system (Biomeraux, France) (13), then after were cultivated in pure cultures, at microbiologicallab at the College of Medicine in University of Babylon.

\section{Agar Well Diffusion Assay forTestingtheIn vitro Antibacterial Activity, NCCLS (14)}

From each bacterial isolates pure culture a loop full growths were inoculated into nutrient 
broth and incubated at temperature of $37^{\circ} \mathrm{C}$ for time of 18-24 hours. Thenthe prepared bacterialsuspensions were diluted with normal saline. The turbidityof suspensions were adjustedand compared with 0.5 McFarland standard tube to yield auniform suspension containing $1.5 \times 10^{6} \mathrm{CFU} / \mathrm{ml}$. Later on, entire Mueller Hinton agar plates surfaces (for all tested bacteria) were streaked by a cotton swab after it wasdipped in the suspension of each suspensionand plateswere left for 5-15 minutes at room temperature to be dried. Four wells of about $(5 \mathrm{~mm}$ in diameter) were made in the mediausing a cork borer and add about $20 \mu \mathrm{l}$ of eachplant extracts solutions or Alum in the wells. Incubate plates at $37^{\circ} \mathrm{C}$ for overnight. After $24 \mathrm{~h}$ of incubation, each zone of inhibition was noted for all extracts and all isolates. The diameters of thezone of inhibitions were measured by measuring scale in millimeter( $\mathrm{mm})$ $(15,16,17)$.

\section{Result}

Medical plant were identified for the effective antibacterial and anti-infection properties in vaginosis. The agar diffusion of aqueous extract from plant extracts(Quercusinfectoria,Matricariachmomilla and chemical material allum)against Staph. aurus,Strepto. agalactiae, E.coli,Enterobacter spp. and Candida albicana.
The Matricariachmomilla showed large inhibition zone against Strep. agalactiae,Staph.aureus, followed byE.coli. The same inhibition zone for Enterobacter spp. ,Candida albicanis, as in Figure (1).

The aqueous extract ofQuercusinfectoriagave inhibition for Strep. agalactiae, E.coli,Staph.aureus, andEnterobacter spp. and Candida albicana, as in Figure (2).

The chemical material Alum had a great potential activity against all the bacterial vaginosis and Vaginal yeast infection which illustrated by the figure (3),which appeared that inhibition zone range from $25-38 \mathrm{~mm}$.

From all thesefiguresStrep agalactiaewas more responsive to the plant extracts. Also, response of bacterial infection to plant extracts was greater than response of yeast infection .

The figure (4) of antibiotic ciprofloxin showed that inhibition zone for Strep. agalactiae $18 \mathrm{~mm}$, E.coli appeared inhibition zone $17 \mathrm{~mm}$, Staph. aureus $15 \mathrm{~mm}$,Enterbacter spp. $14 \mathrm{~mm}$, while Candida albicanisperformed less than $1 \mathrm{~mm}$ inhibition zone.

These results proofed that aqueous plant extracts

ofQuercusinfectoria,Matricariachmomillaand chemical material Alum against bacterial and yeast vaginal infection, gave better effects rather than antibiotic ciprofloxin . 


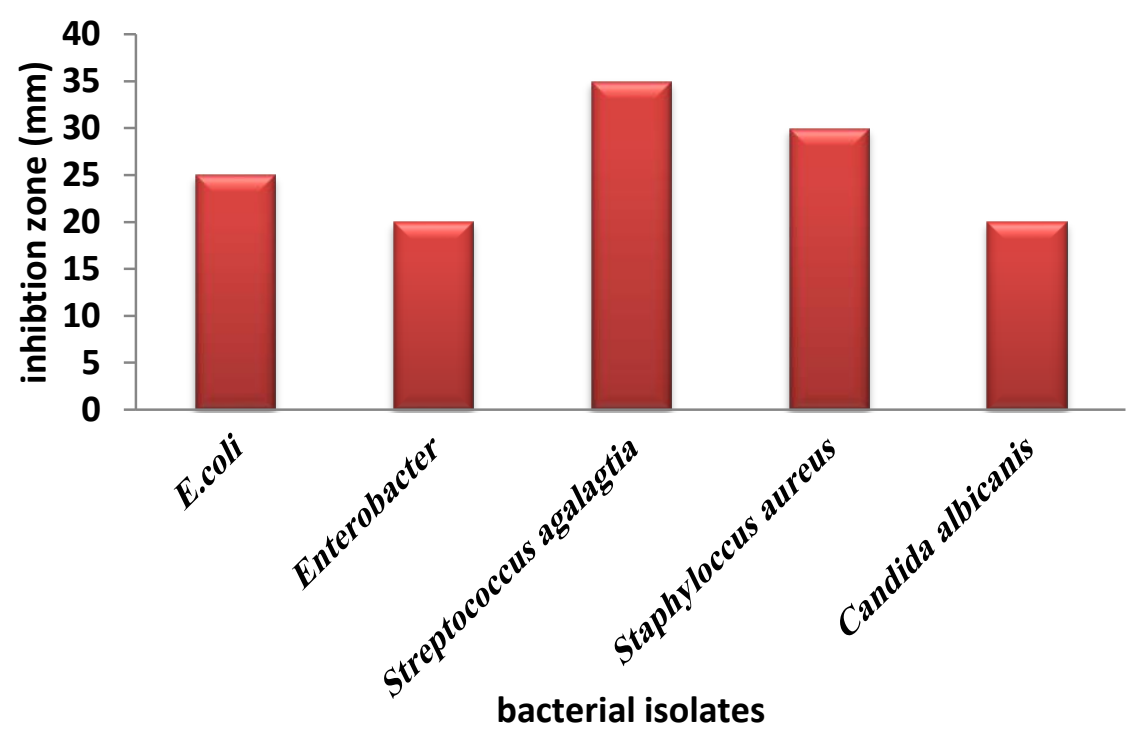

Figure (1): Effect ofMatricariachmomilla(Inhibition Zones (mm)) Against Different Bacterial Isolates from Women

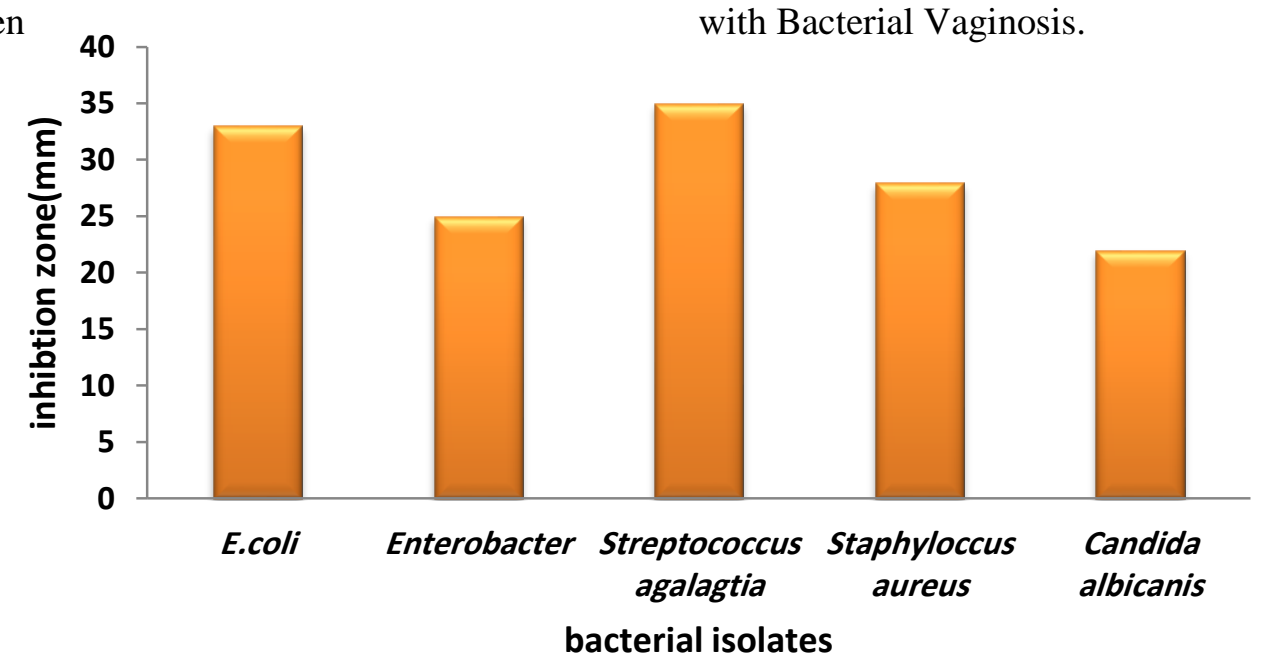

Figure (2): Effect ofQuercusinfectoria (Inhibition Zones (mm)) Against Different Bacterial Isolates from Women with Bacterial Vaginosis. 


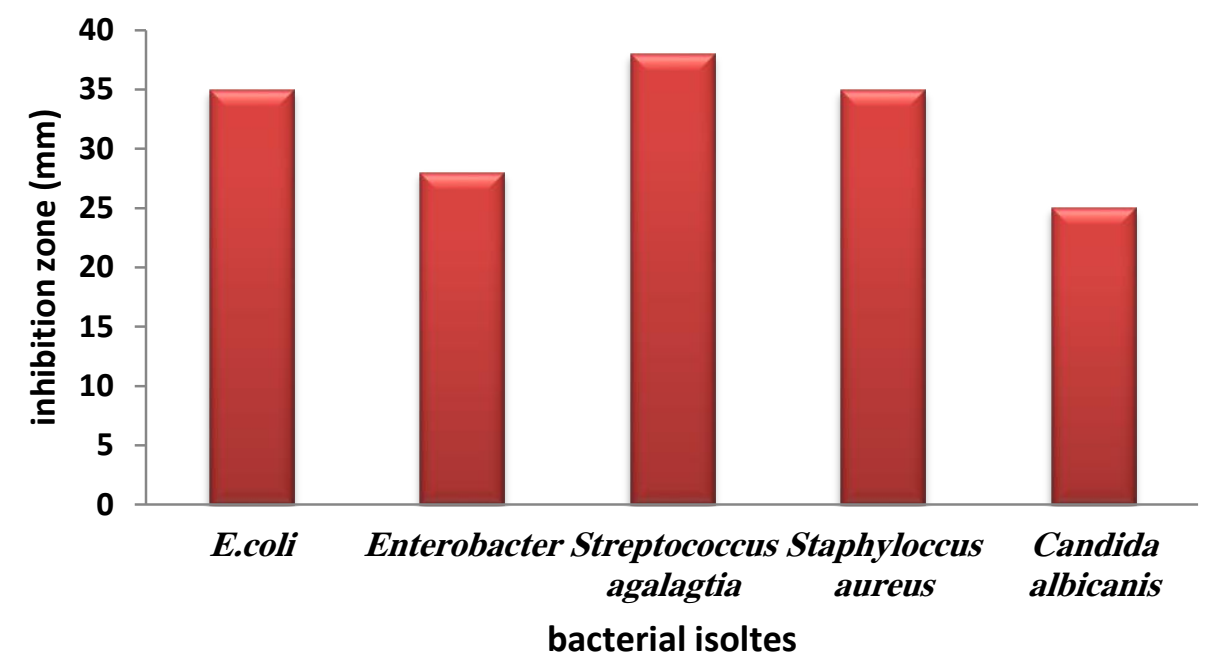

Figure (3): Effect ofAlum (Inhibition Zones (mm)) Against Different Bacterial Isolates from Women with Bacterial Vaginosis.

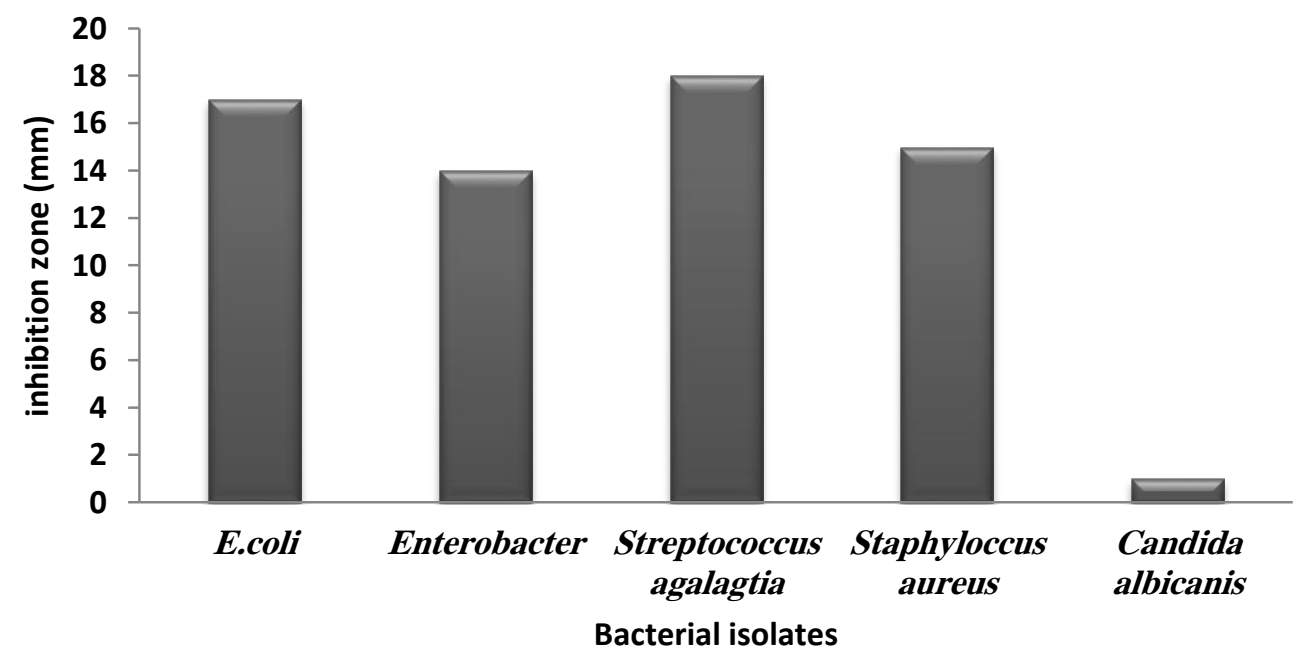

Figure (4): Effect ofCiprofloxacin (Inhibition Zones (mm)) Against Different Bacterial Isolates from Women with Bacterial Vaginosis. 


\section{Discussion}

World have along history of application of traditional medicine and medicinal plants for treatment of bacterial and yeast infection.Our study revealed the probable activity of aqueous extracts of Quercusinfectoria, Matricariachmomillaand chemical material Alum salt as antibacterial agent.Alum salt showed high efficiency against tested bacteria (strep. Agalactiae,staph.aureus, E.coli, Enterobacter spp.and Candida albicana), which represented by inhibition zone range from (25$38 \mathrm{~mm}$ ). These agents have high antibacterial action against Strep. Agalactiae, which have high resistant to macrolides and lincosamides used as alternative drugs for individuals allergic to penicillin(18).

The initial results from this study could initiateto future effort to investigate how Alum salt inhibits growth of the bacteria and potential use of Alum salt. Prior studies have revealed that Alum iseffective against a wide variety of microbial pathogens $(19,20)$ including Klebsiellapneumoniae, Escherichiacoli and Staphylococcus aureus $(21,22)$. The mechanismof bactericidal effect of Alumis not well known(23).Some assumptions trait the antibacterial effect ofAlumin reduction of acidity or toxic effects on bacterial cell wall.

Furthermore, histological studiesconfirm the safety of Alum salt for mammalianconsumption (24).Also in this study these plant had a potential action against all bacterial agents inthe vagina, these agentsare rich in a wide range of secondary active metabolites, such as flavonoids, terpenoids, alkaloids and tannins which have been reportedin vitro to have antimicrobial activities,like chamomile (matricariachamomilla) showed in this study high effect against tested bacteria and yeast.chamomile is excellent in treating any type of inflammation, whether internal or external (25) Chamomile extract, the antimicrobial effects are primarily the result of the active components $\alpha$-bisabolol and azulenes, which have an anti-inflammatory activity (26)

Moreover, other workswere carried out and showed more than 120 chemical constituents, that have been identified in the chamomile flower as secondary active metabolites $(27,28)$ including 36 flavonoids and28 terpenoids $(29,30,31)$ and with additional 52 compounds having potential pharmacological activity (32).

While the aqueous of Quercusinfectoria had influential against this bacteria which used in this study (strep. Agalactiae,staph.aureus ,E.coli, Enterobacter spp.and Candida albicanis)which may be retain to the active compound of theQuercusinfectoria. The research demonstrated the main active elements of the galls are gallic acid (2-4\%), gallotannic acid (50-70\%), starch, sugar and ellagic acid (33).

Quercusinfectoria used for different purposes like its usage as a constituent of toothpaste or toothpowder for the treatment of gum and oral cavity diseases; in the Indian 
traditional medicine(34). The galls have been used to treat menorrhagia tonsillitis, gonorrhea, impetigo,dysentery diarrhea and internal hemorrhages (35).

Pharmacologically, the galls also had been informed to retainperfect activities such as wound healing, antiviral, antibacterial, antidiabetic,antifungal, antiamoebic, antiinflammatory and larvicidal $(36,37)$, which proved by this study against bacteria and yeast.

Our study proof that all this plant extract and Alum salt extracts exhibited a more inhibitory activities on Gram positive bacteria.This result was agreed with many previous studies which had informed that the growth of Gram-positive bacteria was definitely inhibited by natural extracts of plant compared to Gram-negative bacteria (38). The reason for this variancemay be attributed to the difference in bacterial cell wall structure and composition (39).

\section{Reference}

1. De Leo V., and Benvenuti C. 2015. Pharmacological,Microbiological and Clinical Activity of Feminie Intimate cleansers based on plant extracts active principles(Saugella Line).J.woman's Health Care 4:244.

2. Machado D., Castro J.,Palmeira-de Oliveira A., Martinez -de-Oliveira J. and Cerca N.2015. Bacterial vaginosis biofilms: challenges to current therapies and emerging solution.Front Microbiol., 6:1528.
3. "Vaginal yeast infections fact sheet". womenshealth.gov. December 23, 2014. Retrieved 5 March 2015.

4. Zhang X.2004. Traditional medicine: its importance and protection, in protecting and promoting traditional knowledge: systems, national experiences and international dimension, part 1, the role of traditional knowledge in healthcare and agriculture, S.Twarge and P.Kapoor, eds., 3-6.

5. Tadeg H., Mohammed E., AsresK., and Gebre-Mariam T. 2005. Antimicrobial activities of some selected traditional Ethiopian medicinal plants used in the treatment of skin disorders," J. Ethnopharmacol., 100 (12): 168-175.

6. Silva J., Abebe W., Sousa S.M., Duarte V.G., Machado M.I.L., and Matos F.J.A.2003. "Analgesic and antiinflammatory effects of essential oils of Eucalyptus," J. Ethnopharmacol., 89(23) 277-283.

7. Dubey R, Dubey K, Sridhar C, Jayaveera KN. 2011. Human VaginalPathogen Inhibition Studies On Aqueous, Methanolic And Saponins Extracts of Stem Barks Of ZiziphusMauritiana. Int. J.Pharm. Sci. Res.2(3): 659-663.

8. Kamali HH, Amir MY. 2010. Antibacterial Activity and Phytochemical Screening of Ethanolic Extracts Obtained from Selected Sudanese Medicinal Plants. Curr. Res. J. Bio. Sci; 2(2):143-146.

9. Lalitha P, Arathi KA, Shubashini K, Sripathi, Hemalatha, S, Jayanthi P.2010. Antimicrobial Activity and Phytochemical Screening of an Ornamental Foliage Plant, Pothosaurea(Linden ex Andre). Int. J. of Chem; 1 (2): 63-71 
10. Edeoga HO, Okwu DE, Mbaebie BO 2005. Phytochemical constituents of some Nigerian medicinal plants.Afri. $J$. Biotechnol.4:685-688.

11. Ahmed Saleem Abbas;Jeberson W, Klinsega V V. 2012. A Literature Review and Classification of Selected Software Engineering Researches", International Journal of Engineering and Technology., 2(7): 1256-1282.

12. Onyeagba RA, Ugbogu OC. Okeke CU. and Iroakasi O.2004. Studieson the Antimicrobial effects of garlic (Allium sativum Linn), ginger (Zingiberofficinale Roscoe) and lime (Citrus aurantifoliaLinn). African $J$ Biotech;; 3 (10): 552-554.

13. Hindi NKK. 2013. In vitro Antibacterial Activity of Aquatic Garlic Extract, Apple Vinegar and Apple Vinegar Garlic Extract combination.American $J$ Phytomedicine and Clinic Therapeutics (1): 042-051.

14. Forbes BA, Sahm DF and Weissfeld AS. Bailey and Scotts 2007.Diagnostic microbiology 12th. ed. Elsevier China.

15. HindiN. K. 2016. Bacteriological Study of Pigmented Bacteria and Molecular Study Based for 16s rRNA Gene. Research Journal of Pharmaceutical, Biological and Chemical Sciences., 7(6): 258-266.

16. HindiN. K. 2016. In vitro Antibacterial activity of Plants extracts against Porphyromonasgingivalis, Prevotella intermedia and Aggregatibacteractinomycetemcomitans Streptococcus mutanus, Isolated from Periodontitis Patients in Babylon province, Iraq. International Journal of PharmTech Research, 9(11):84-93.

17. HindiN. K., Abdul-Husin, IF, Jebur,MH.,Al-Mahdi, ZK.,Kadhim, AK.2017. Evaluation of anti-bacterial activity of the aquatic henna leaves extract in Hilla City, an in vitro study, Journal of Chemical and Pharmaceutical Sciences, Iraq, Journal of Chemical and Pharmaceutical Sciences., 10 (1): 162-165.

18. Bolukaoto J. Y., Monyama C.M, Chukwu M.O., Lekala S.M., Nchabeleng M., Maloba M.R.B., Mavenyengwa R.T.,Lebelo S.L., Monokoane S.T., Tshepuwane C., and Moyo S.R. 2007. Antibiotic resistance of Streptococcus agalactiae isolated from pregnant women in Garankuwa, South AfricaAfr J Tradit Complement Altern Med. ; 4(3): 338-344.

19. Dutta S, De SP, Bhattacharya SK. 1996. In vitroantimicrobial activity of potash Alum. Indian JMed Res.; 104:157-9.

20. Mourughan K, Suryakanth MP. 2004. Evaluation of anAlum-containing mouthrinse for inhibition ofsalivary streptococcus mutans levels in children-acontrolled clinical trial. $J$ Indian SocPedodPrevDent.;22(3):100-5.

21. Bestoon MF. 2012. Evidence for feasibility of Aluminum potassium sulfate (Alum) solution as a root canalirrigant. J Coll Dent UinvBagh.; 24(1):1-5.

22. Bnyan IA, Alta'ee AH, Kadhum NH. 2014. AntibacterialActivity of Aluminum Potassium Sulfate andSyzygiumAromaticum Extract AgainstPathogenic Microorganisms. $J$ Nat Scie Res.

23. Arul Prakash F, Babu GD, Lavanya M, VidhyaKS, Devasena T. 2011. Toxicity Studies of AluminiumOxide Nanoparticles in Cell Lines. Int JNanotechnol Appl.; 5(2):99-107.

24. Osuala FI, Ibidapo-obe MT, Okoh HI, Aina O, Igbasi UT, Nshiogu ME, Onubogu CC, EgbunaKN, Ajibaye O, 
Orok AB. 2009. Evaluation of the efficacy and safety of Potassium AluminiumTetraoxosulphate

(Vi)

(ALUM) in the Treatment of tuberculosis. Eur J BioloScie.; 1(1):105.

25. Abebe W. 2002. Herbal medication: Potential for adverse interactions with analgesic drug. $J$ Clin Pharm Therapeut.;27:391-401

26. Barene I, Daberte I, Zvirgzdina L, Iriste $\mathrm{V}$. The complex technology on products of chamomile. Medicina (Kaunas) 2003;39:127-31.

27. Pino JA, Bayat F, Marbot R, Aguero J. 2002. Essential oil of Chamomillarecutita (L.) Rausch. From Iran. J Essent Oil Res.;14:407-8.

28. Pirzad A, Alyari MR, Shaliba S, Zehtab-Salmasi, Moammadi A. 2006. Essential oil content and composition of German chamomile (Matricariachamomilla L.) at different irrigation regimes. J Agron.;5:451-5.

29. Exner J, Reichling J, Becker H. 1980. Flavonoid in Matricaria chamomile. Planta Med:;39:219-30.

30. Kunde R, Isaac O. 1980. On the flavones of chamomile

(Matricariachamomilla L.) and a new acetylated apigenin-7-glucoside. Planta Med.;37:124-30

31. . Isaac O. 1980. Therapy with chamomile-experience and verification. DischApothZtg.;120:567-70.

32. Manday E, Szoke E, Muskath Z, Lemberkovics E. 1999. A study of the production of essential oils in chamomile hairy root cultures. Eur $J$ Drug MetabPharmacokinet.;24:303-8.

33. J. Bruneton, 1999.Pharmacognosy, Phytochemistry, Medicinal Plants, Intercept, Hampshire, UK, 2nd edition,.
34. C. P. Khare, Indian Medicinal Plants: An Illustrated Dictionary, Springer, Berlin, Germany, 2007.

35. P. K. Warrier, V. P. K. Nambiar, and C. Ramankutty, 1995. Indian Medicinal Plants, Orient Longman, Madras, India, 4th edition,.

36. J. K. Hwang, T. W. Kong, N. I. Baek, and Y. R. Pyun, 2000 " $\alpha$-Glycosidase inhibitory activity of hexagalloylglucose from the galls of Quercusinfectoria," Planta Medica, vol. 66, no. 3, pp. 273-274,.

37. S. P. Umachigi, K. N. Jayaveera, C. K. A. Kumar, et al., 2008 "Studies on wound healing properties of Quercusinfectoria," Tropical Journal of Pharmaceutical Research, vol. 7, pp. 913-919,.

38. J. Lin, A. R. Opoku, M. Geheeb-Keller et al., 1999. "Preliminary screening of some traditional zulu medicinal plants for anti-inflammatory and antimicrobial activities," J. Ethnopharmacol, 68(1-3): 267-274,.

39. P. W. Grosvenor, A. Supriono, and D. O. Gray, 1995."Medicinal plants from Riau Province, Sumatra, Indonesia. Part 2: antibacterial and antifungal activity," Journal of Ethnopharmacology, vol. 45, no. 2, pp. 97-111,. 


\section{تأثير مستخلصات الجفت والبابونج والثب ضد البكتريا المعزولة من نساء تعاني التهاب المهبل}

ا.م. ندى خزعل هندي /كليه التمريض جامعه بابل م. لبنى عبد المطلب الثلاه /مركز بحوث ودراسات البيئه جامعه بابل م· زينب عادل جابك /كليه الطب جامعة بابل ويعتبر مستخلصاتالنباتات مواد طبيعية وآمنة، يمكن الوصول إليها وغير مكلفة وقد زرعت لعلاج العدوى البكتيرية.

أجريت هذه الدراسة لتحديد النثاط المثبط لجفت، البابونج والثب على التهاب المهيل البكتيري والعدوى الخمائر المهبلية.

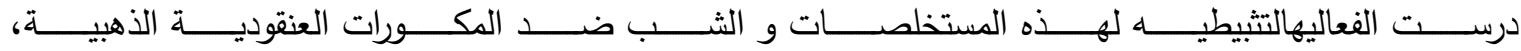

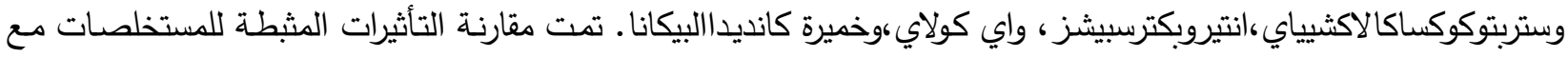
السيبروفلوكساسين.

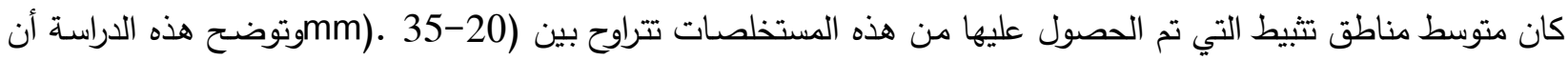

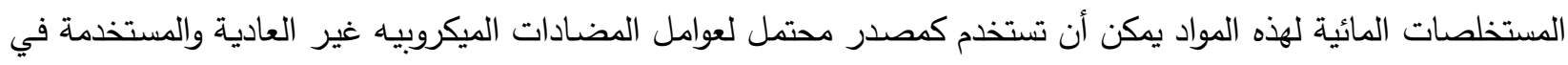
التهاب المهبل البكتيري وعدوى الخميرة المهبلية. أيضا، كانت الالتهابات البكتيرية هي أعلى استجابة للمستخلصات النباتية قياسابعدوى الخميرةالمهبليه، خاصة بكتيريا ستربتوكوكسأغالاكثياي.

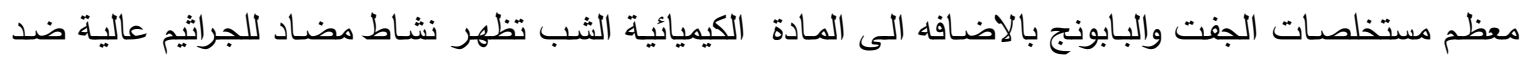
أسباب مختلفة من المهبل، وبالتالي هذه المستخلصات الطبيعية يمكن أن توفر الحماية إلى حد ما ضد الأعداء الطبيعية 